\title{
OPEN Silicon and mechanical damage increase polyphenols and vitexin in Passiflora incarnata L.
}

\author{
Jonas Akenaton Venturineli Pagassini ${ }^{1}$, Leandro José Grava de Godoy ${ }^{2}$, \\ Felipe Girotto Campos ${ }^{3 凶}$, Gustavo Ribeiro Barzotto ${ }^{1}$, Maria Aparecida Ribeiro Vieira ${ }^{3}$ \& \\ Carmen Sílvia Fernandes Boaro ${ }^{1}$
}

Passiflora incarnata L. is a species of global pharmacological importance, has not been fully studied in the context of cultivation and management. It is known that silicon acts on abiotic stress and promotes phenols synthesis. The practice of mechanical damage is widely used in $P$. incarnata crops, and its interaction with silicon can have a significant influence on plant metabolism. Therefore, our objective was to investigate the effects of silicon and mechanical damage on photosynthesis, polyphenols and vitexin of $P$. incarnata. The experiment was conducted in a factorial design with $\mathrm{SiO}_{2}$ concentrations $(0,1,2,3 \mathrm{mM})$ and presence or absence of mechanical damage. It was found that mechanical damage improved photosynthetic performance at lower concentrations or absence of silicon. Moreover, this condition promoted an increasing in vitexin concentration when $\mathrm{SiO}_{2}$ was not provided. The application of $3 \mathrm{mM} \mathrm{Si}$ is recommended to increase polyphenols and vitexin, without harming dry mass of aerial part. The interaction between silicon and mechanical damage could be a tool to increase agronomic yield and commercial value of the $P$. incarnata crop.

Passiflora incarnata L. is a perennial tropical plant with a climbing herbaceous habit, whose center of origin is in the southeastern United States ${ }^{1-3}$, being also cultivated in other countries of the American continent, Europe, Asia, Africa and Australia. It is studied in the pharmacological field because presents chemical substances of interest to health and is a component of anxiolytic drugs ${ }^{4-7}$.

The species is part of the United States Pharmacopeia (U.S.P) and European Pharmacopoeia and it is cataloged in the National List of Medicinal Plants of Interest to the Unified Health System (RENISUS list-Brazil) ${ }^{8}$.

Passiflora incarnata has medicinal potential for social impact, with neurogenic action and beneficial to functions related to memory and learning ${ }^{6}$. Regarding this potential, vitexin is a flavone that presents antioxidant, cardioprotective, anticarcinogenic, anti-inflammatory, antidiabetic, and anticonvulsant actions ${ }^{9-13}$. Diseases related to the nervous system have become increasingly common, with increased occurrences of depression and anxiety ${ }^{13,14}$, which suggests that researches with this species should be expanded.

While recent studies address the cultivation, nutrition and management of $P$. incarnat ${ }^{15-18}$ few studies have focused on increasing bioactive molecules synthesis. Beneficial elements, such as silicon ( $\mathrm{Si}$ ), are an alternative for a better performance of agricultural crops and their effects are observed in plants subjected to stress, presenting better photosynthetic performance, greater growth and phenolic compounds accumulation. These effects are explained by the greater activity of antioxidant enzymes and the phenylalanine ammonia-lyase (PAL), which acts in the pathway of phenols and other molecules with medicinal importance ${ }^{19-22}$.

Si can act as a signal for the genes expression in the photochemical stage and for other genes that activate enzymes, participating in the polyphenols and flavonoids synthesis ${ }^{19-22}$. In addition, the element can be complexed with phenolic compounds, making them insoluble, expanding their mobility in the apoplast due to the transpiration flow and also stimulating the biosynthesis of these compounds, based on the genes expression from the PAL pathway, promoted by higher Si concentrations ${ }^{23,24}$.

Beneficial effects of Si have already been reported for Passiflora edulis Sims. ${ }^{25,26}$, who verified its deposition in the cell wall epicuticle, besides the increase in stomatal conductance, $\mathrm{CO}_{2}$ assimilation rate, transpiration rate, dry mass of leaves and root. However, the higher Si concentration used in the mentioned study reduced the chlorophyll concentration, which indicates that the element concentration is crucial to obtain beneficial results.

${ }^{1}$ School of Agriculture, São Paulo State University, Botucatu, Brazil. ${ }^{2}$ Campus of Registro, São Paulo State University, Registro, Brazil. ${ }^{3}$ Institute of Biosciences, São Paulo State University, Botucatu, Brazil. ${ }^{\otimes}$ email: felipe.girotto@unesp.br 

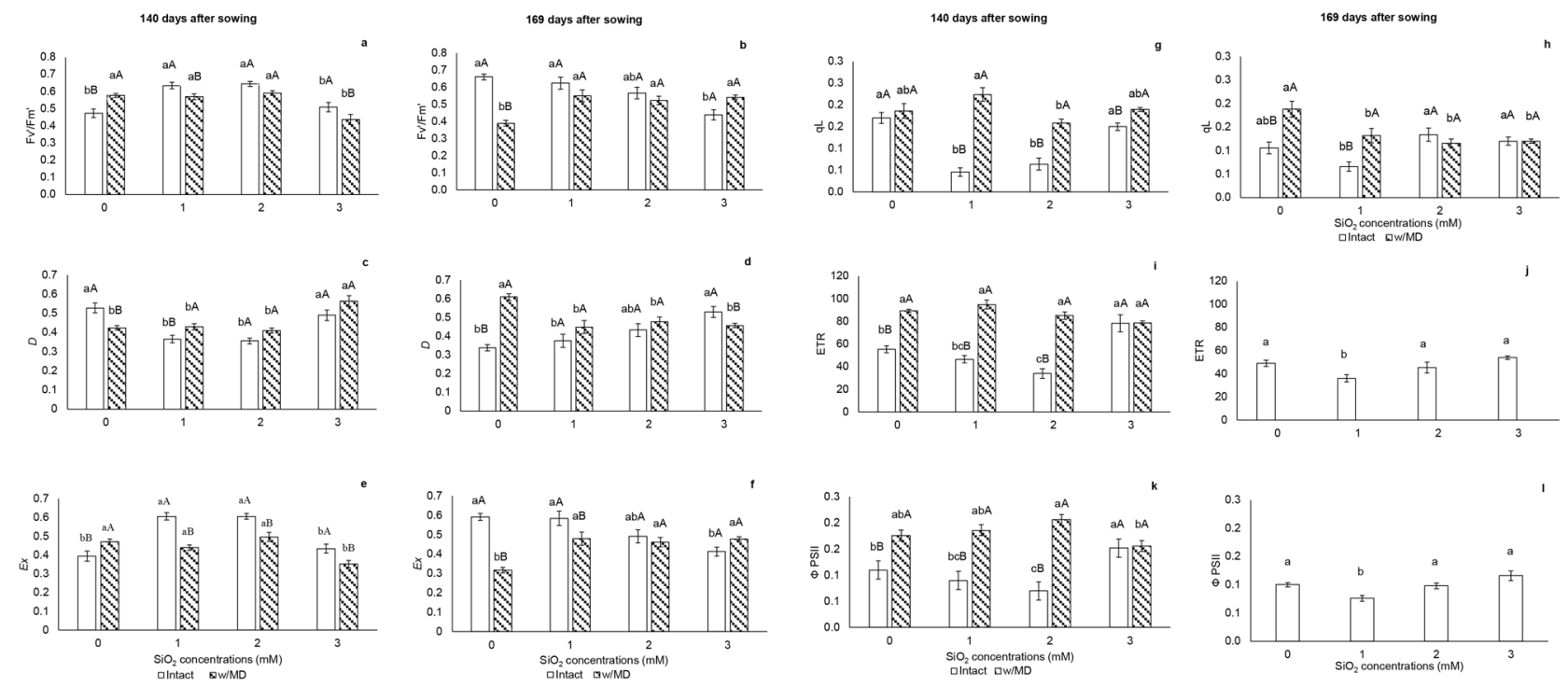

Figure 1. Chlorophyll $a$ fluorescence. (a,b) Potential quantum efficiency of open PSII center $\left(\mathrm{Fv}^{\prime} / \mathrm{Fm}^{\prime}\right) \mathrm{p}<0.01$; (c,d) energy fraction absorbed by PSII antenna that is dissipated as heat $(D) \mathrm{p}<0.01 ;(\mathbf{e}, \mathbf{f})$ energy fraction not dissipated in the antenna that cannot be used for photochemistry stage $(E x) \mathrm{p}<0.01 ;$ (g,h) photochemical quenching $(\mathrm{qL}) \mathrm{p}<0.01 ;(\mathbf{i}, \mathbf{j})$ electron transport rate $(\mathrm{ETR}) \mathrm{p}<0.01,(\mathbf{k}, \mathbf{l})$ effective quantum efficiency of photosystem II (ФPSII) $\mathrm{p}<0.01$ in Passiflora incarnata L. with mechanical damage (w/MD) and without mechanical damage (intact), subjected to $\mathrm{SiO}_{2}$ variations at 140 and 169 days after sowing. Values corresponding to the averages \pm SE. Capital letters compare plants with and without mechanical damage and lower letters compare $\mathrm{SiO}_{2}$ variations. ETR and PSII results were significant only for $\mathrm{SiO}_{2}$ variations. Other results were significant for the interaction between $\mathrm{SiO}_{2}$ variations and the presence/absence of mechanical damage.

In the commercial crops of $P$. incarnata more than one harvest is expected, enabling a continuous supply of leaves and stems to the pharmaceutical production chain ${ }^{27}$. The complete harvesting of the aerial part promotes mechanical damage, which can signal the production of phenolic compounds, since this stress may be influence the activity of the PAL enzyme and other enzymes in the polyphenol pathway ${ }^{28}$.

The Si supply and mechanical damage can result in an increase in biomass and active molecules, contributing to the production chain of the species. The objective of this study was to investigate the Si and mechanical damage effects on photosynthetic metabolism and on the polyphenols and vitexin synthesis in P. incarnata.

\section{Results}

Chlorophyll $\boldsymbol{a}$ fluorescence and gas exchange. In the absence of silicon, the potential quantum efficiency of the open reaction center $\left(\mathrm{Fv}^{\prime} / \mathrm{Fm}^{\prime}\right)$ at 140 days after sowing (DAS) was higher in plants that received mechanical damage. In the absence of damage, at $169 \mathrm{DAS}, \mathrm{Fv}^{\prime} / \mathrm{Fm}^{\prime}$ was lower in plants grown with $3 \mathrm{mM} \mathrm{SiO}_{2}$ (Fig. 1a,b).

At 140 DAS, plants that received mechanical damage and cultivated with 1 and $2 \mathrm{mM} \mathrm{SiO}_{2}$ showed higher photosystem performance, represented by photochemical quenching (qL), electron transport rate (ETR) and effective quantum efficiency of photosystem II (ФPSII) than intact plants at the same concentrations (Fig. 1g,i,k). In the absence of mechanical damage, energy fraction absorbed by PSII antenna that is dissipated as heat $(D)$ was higher and energy not dissipated and not used for the photochemical phase $(E x)$ was lower in plants subjected to 0 and $3 \mathrm{mM} \mathrm{SiO}_{2}$, which may indicate photoprotection (Fig. 1c,e).

At 169 DAS, regardless the damage, plants cultivated at concentration $1 \mathrm{mM} \mathrm{SiO}_{2}$ showed lower ETR and ФPSII (Fig. 1j,l). Among plants that did not receive Si, those that received mechanical damage had higher $D$ and $\mathrm{qL}$ and lower Ex compared to intact plants (Fig. 1d,f,h).

At 140 DAS plants subjected to damage had higher transpiration rate $(E)$ regardless the $\mathrm{SiO}_{2}$ level (Fig. 2a). At 169 DAS, plants with 2 and $3 \mathrm{mM} \mathrm{SiO}_{2}$ with mechanical damage showed high transpiration rate. Among intact plants, those with Si had a lower $E$ (Fig. 2b).

Stomatal conductance $\left(g_{s}\right), \mathrm{CO}_{2}$ assimilation rate $\left(A_{n e t}\right)$ and RuBisCO carboxylation efficiency $\left(A_{\text {net }} / C_{i}\right)$ were higher at $140 \mathrm{DAS}$ in plants subjected to mechanical damage, except for plants grown with $3 \mathrm{mM} \mathrm{SiO}_{2}$ (Fig. 2c,e,g). At $169 \mathrm{DAS}, g_{s}, A_{\text {net }}$ and $A_{\text {net }} / C_{i}$ were higher in plants with damage at the highest $\mathrm{SiO}_{2}$ concentrations (Fig. 2d,f,h).

Hydrogen peroxide and lipid peroxidation. Plants with $1 \mathrm{mM} \mathrm{SiO}_{2}$ showed a higher concentration of hydrogen peroxide $\left(\mathrm{H}_{2} \mathrm{O}_{2}\right.$ ) when damage occurred. In intact plants, $\mathrm{SiO}_{2}$ supply reduced hydrogen peroxide, except for the $2 \mathrm{mM} \mathrm{SiO}_{2}$ concentration. (Fig. 3a). In the mechanical damage absence, lipid peroxidation, presented as malondialdehyde concentration (MDA) was higher in plants grown with $\mathrm{SiO}_{2}$ and in the presence of mechanical damage, there was no difference between plants (Fig. 3b). 
140 days after sowing
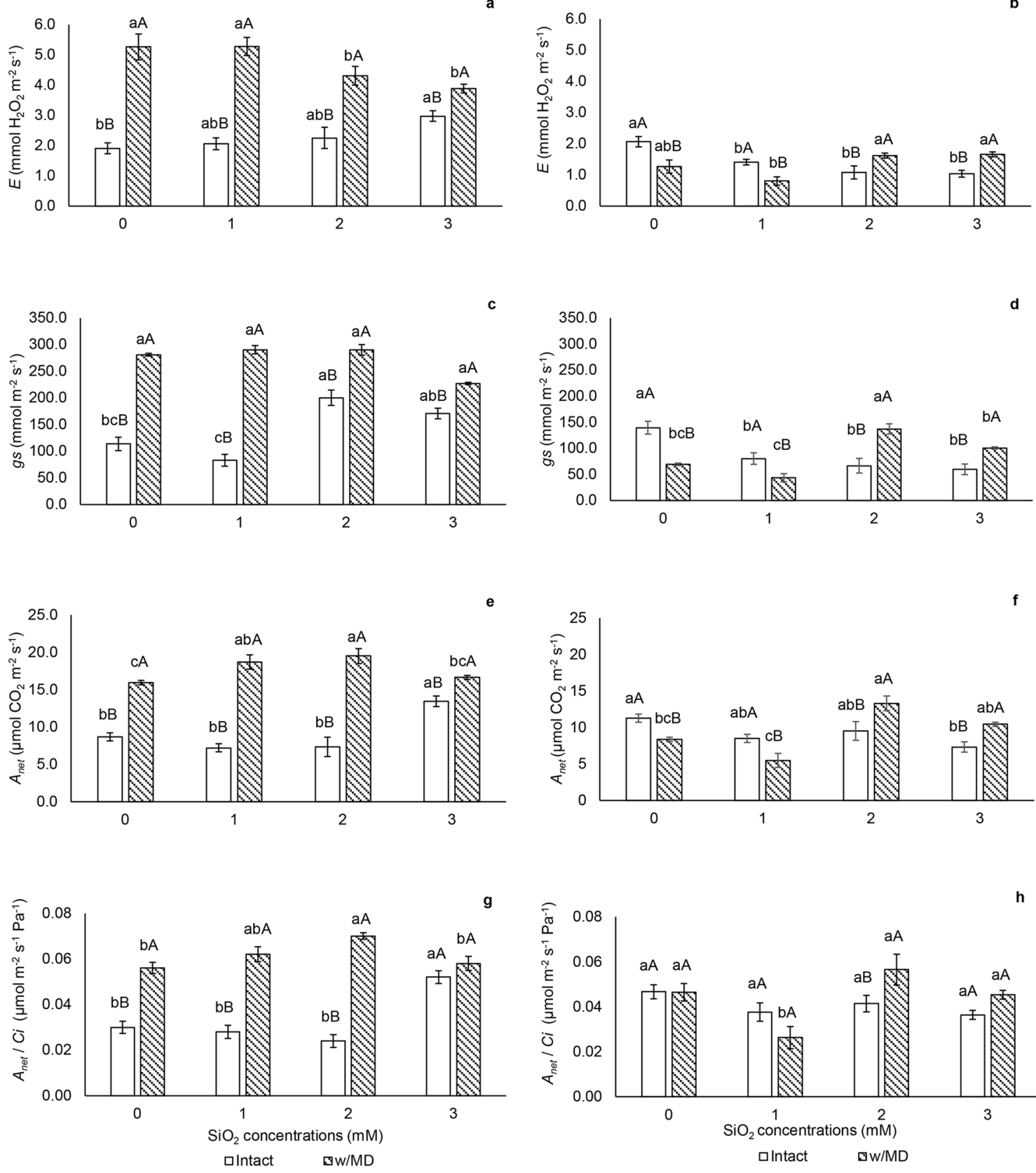

169 days after sowing

b
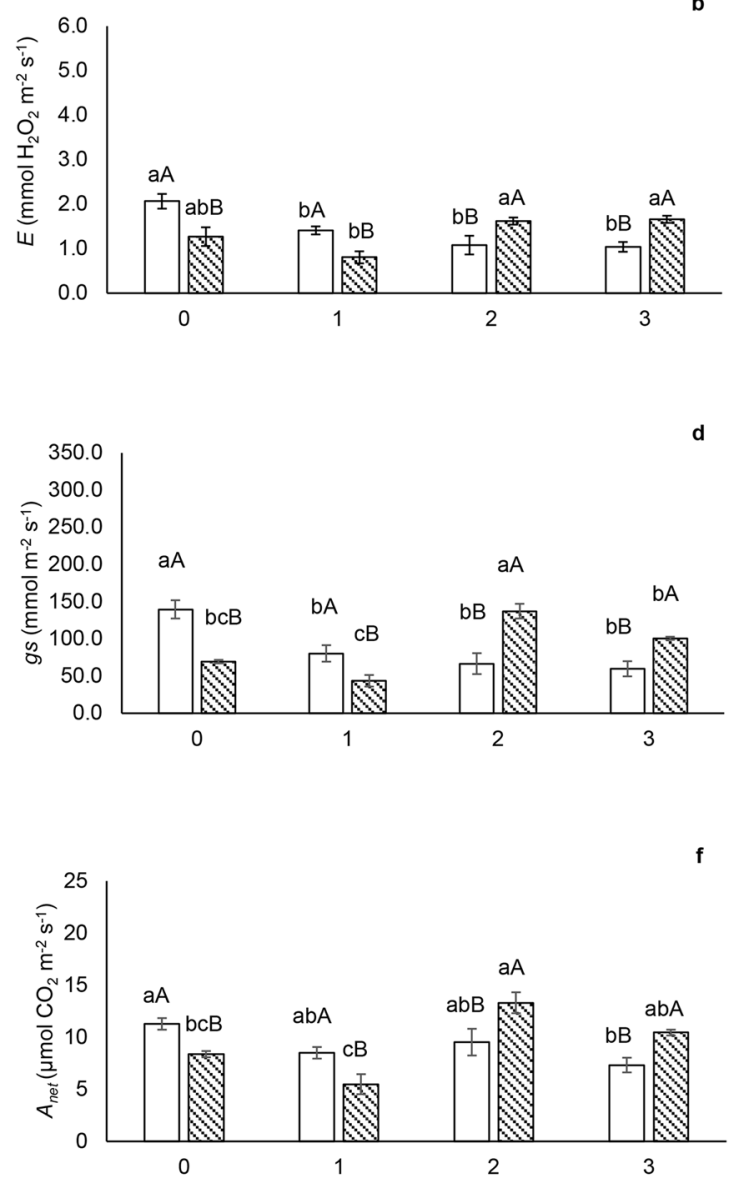

h

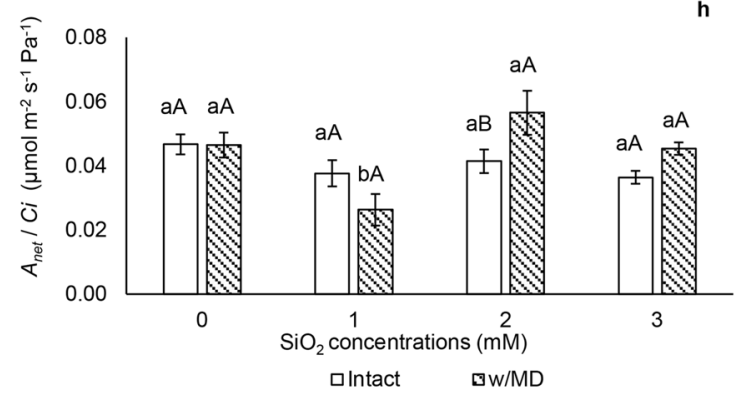

Figure 2. Gas exchange. (a,b)Transpiration rate $\left(E, \mathrm{mmol} \mathrm{H}_{2} \mathrm{O} \mathrm{m}^{-2} \mathrm{~s}^{-1}\right) \mathrm{p}<0.01 ;$ (c,d) stomatal conductance $\left(g_{s}, \mathrm{mmol} \mathrm{m} \mathrm{m}^{-1}\right) \mathrm{p}<0.01 ;(\mathbf{e}, \mathbf{f}) \mathrm{CO}_{2}$ assimilation rate $\left(A_{\text {net }}, \mu \mathrm{mol} \mathrm{CO}_{2} \mathrm{~m}^{-2} \mathrm{~s}^{-1}\right) \mathrm{p}<0.01 ;(\mathbf{g}, \mathbf{h}) \mathrm{RuBisCO}$ carboxylation efficiency $\left(A_{\text {net }} / C_{i}, \mu \mathrm{mol} \mathrm{m}^{-2} \mathrm{~s}^{-1} \mathrm{~Pa}^{-1}\right) \mathrm{p}<0.03$ in Passiflora incarnata L. with mechanical damage (w/MD) and without mechanical damage (intact), subjected to $\mathrm{SiO}_{2}$ variations at 140 and 169 days after sowing. Values corresponding to the averages $\pm \mathrm{SE}$. Capital letters compare plants with and without mechanical damage and lower letters compare $\mathrm{SiO}_{2}$ variations.

Polyphenol index and vitexin. Higher polyphenol content was revealed by plants grown with $3 \mathrm{mM} \mathrm{SiO}_{2}$ and plants grown with 1 and $2 \mathrm{mM} \mathrm{SiO}_{2}$ showed intermediate concentrations, not differing from each other. In this evaluation, there was no significant effect of mechanical damage or even its interaction with $\mathrm{SiO}_{2}$ levels (Fig. 3c).

Plants collected at 169 DAS, regardless the mechanical damage, had the highest vitexin content with $3 \mathrm{mM}$ $\mathrm{SiO}_{2}$ (Fig. 3d). Plants grown without $\mathrm{Si}$ and with mechanical damage showed a higher content of vitexin when compared to intact plants (Figs. $3 \mathrm{~d}$ and 4 ).

Carbohydrates. Plants without silicon subjected to mechanical damage showed investment in reserve carbohydrates, such as starch, while intact plants showed high total soluble sugars concentrations (Fig. 5a,d). 

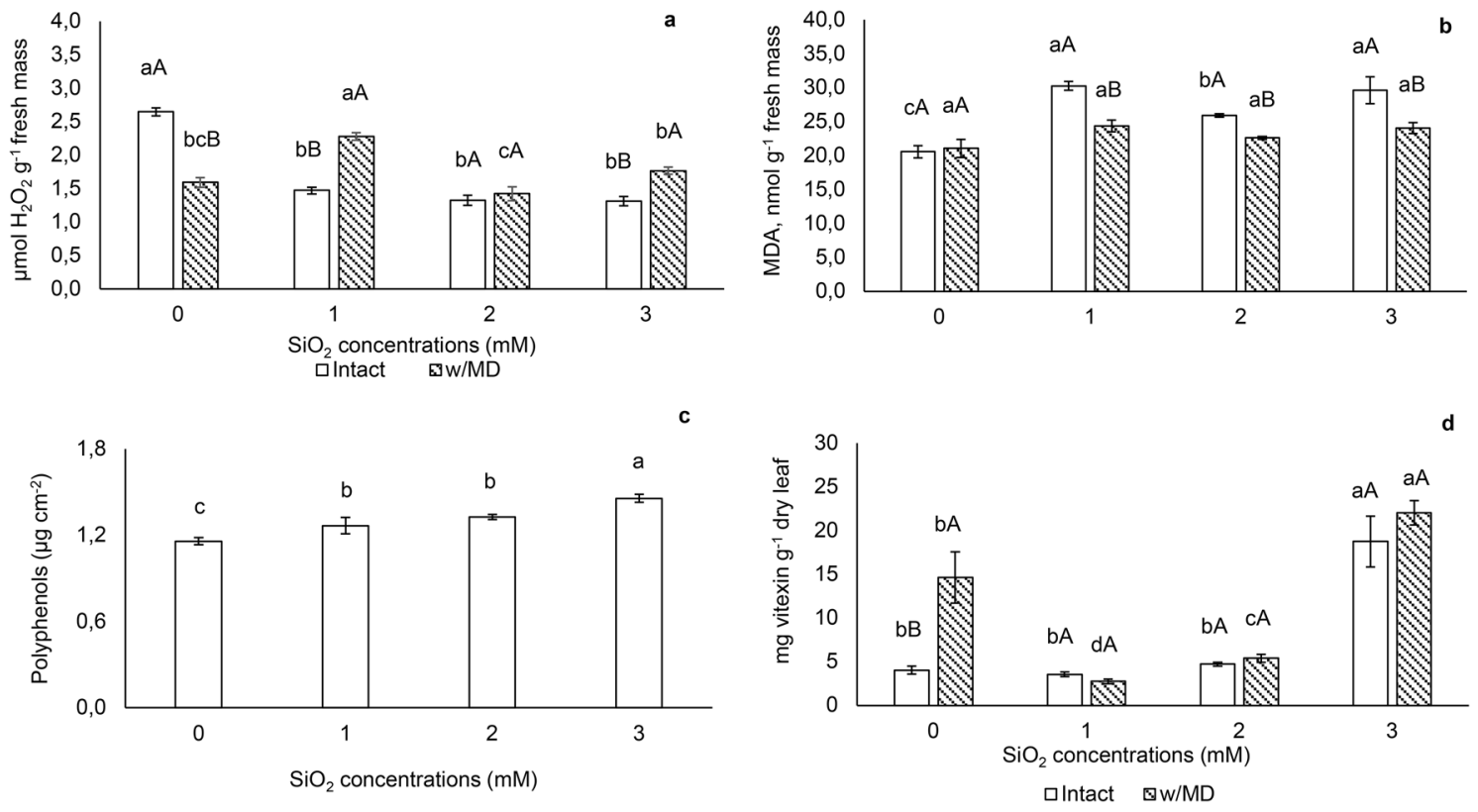

Figure 3. (a) Hydrogen peroxide, (b) lipid peroxidation, (c) polyphenols and (d) vitexin concentration. $\mathrm{H}_{2} \mathrm{O}_{2}$ $\mathrm{p}<0.05$; lipid peroxidation expressed by the formation of malonaldehyde (MDA) $\mathrm{p}<0.05$; polyphenols $\mathrm{p}<0.01$; vitexin $\mathrm{p}<0.01$ in Passiflora incarnata L. with mechanical damage (w/MD) and without mechanical damage (intact), subjected to $\mathrm{SiO}_{2}$ variations. Values corresponding to the averages \pm SE. Capital letters compare plants with and without mechanical damage and lower letters compare $\mathrm{SiO}_{2}$ variations. Polyphenols results were significant only for $\mathrm{SiO}_{2}$ variations. Other results were significant for the interaction between $\mathrm{SiO}_{2}$ variations and the presence/absence of mechanical damage.

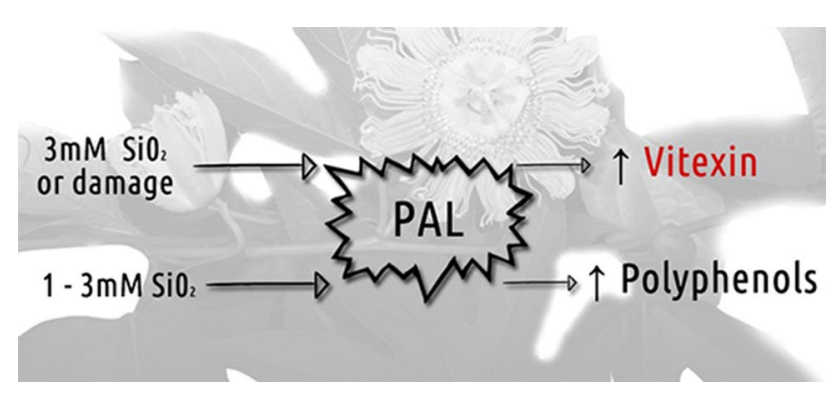

Figure 4. Simplified scheme of silicon action and mechanical damage in Passiflora incarnata L., in increasing the activity of the enzyme phenylalanine ammonia-lyase (PAL), resulting in an increase in polyphenols and vitexin $^{23}$.

Plants with mechanical damage showed a high amount of total soluble sugars when grown with $2 \mathrm{mM} \mathrm{SiO}_{2}$. Intact plants showed a lower amount of total soluble sugars with $3 \mathrm{mM} \mathrm{SiO}_{2}$ (Fig. 5a). Plants subjected to mechanical damage showed a higher amount of reducing sugars, regardless the $\mathrm{SiO}_{2}$ concentration (Fig. 5b).

Intact plants with $3 \mathrm{mM} \mathrm{SiO}_{2}$ showed lower sucrose concentration when compared to intact plants without $\mathrm{Si}$. In plants with mechanical damage, the highest concentration of sucrose was found in plants with $1 \mathrm{mM} \mathrm{SiO}_{2}$, which did not differ from plants without Si (Fig. 5c).

Among plants cultivated without $\mathrm{Si}$ and with $3 \mathrm{mM} \mathrm{SiO}_{2}$, those with mechanical damage showed higher starch accumulation. In general, plants grown with $1 \mathrm{mM} \mathrm{SiO}_{2}$, and damage showed less starch accumulation. In the intact plants, the starch concentration did not differ (Fig. 5d).

Growth indices. Plants cultivated with $2 \mathrm{mM} \mathrm{SiO}_{2}$ showed higher dry mass of leaves (LDM) and total (TDM), highlighting that in TDM, plants with $2 \mathrm{mM} \mathrm{SiO}_{2}$ did not differ from those with lower concentration or $\mathrm{Si}$ absence. When $3 \mathrm{mM} \mathrm{SiO}_{2}$ was provided, TDM was reduced (Fig. 6a). The leaf mass ratio (LMR) was higher in plants that received $2 \mathrm{mM} \mathrm{SiO}_{2}$, not different from plants grown with 1 and $3 \mathrm{mM} \mathrm{SiO}_{2}$ (Fig. 6b).

The LMR expresses the plant area useful for photosynthesis, resulting in plant mass, and the specific leaf area (SLA) data reveal area per leaf mass, indicating its thickness (Fig. 6c). The concentration of $2 \mathrm{mM} \mathrm{SiO}_{2}$ increased the LMR and $1 \mathrm{mM} \mathrm{SiO}_{2}$ decreased SLA compared to control plants. 

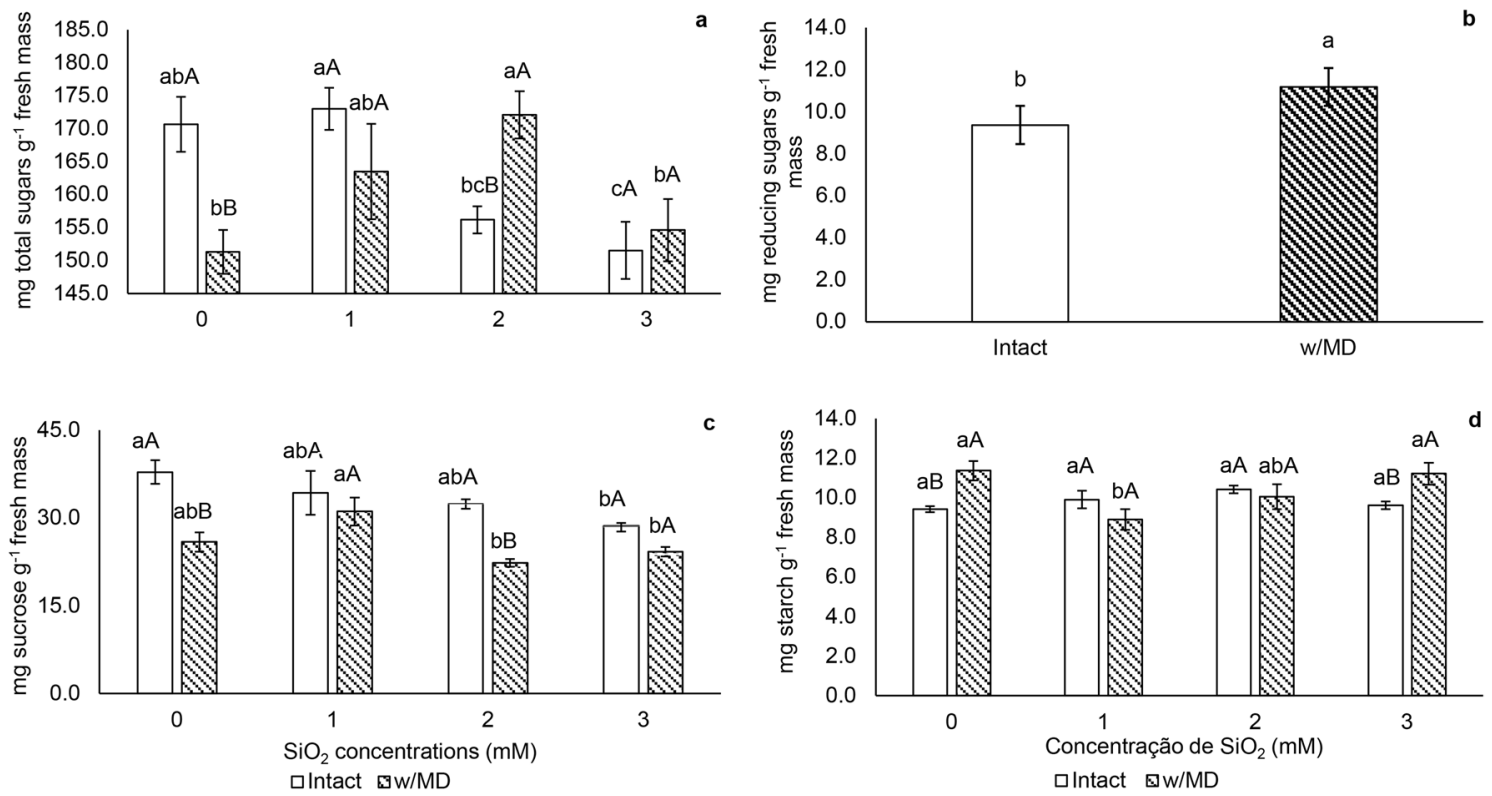

Figure 5. Carbohydrates. (a) Total sugars ( $\mathrm{p}<0.05)$; (b) reducing sugars $(\mathrm{p}<0.04)$; (c) sucrose $(\mathrm{p}<0.04)$; (d) starch $(\mathrm{p}<0.05)$ in Passiflora incarnata L. with mechanical damage (w/MD) and without mechanical damage (intact), subjected to $\mathrm{SiO}_{2}$ variations. Values corresponding to the averages $\pm \mathrm{SE}$. Capital letters compare plants with and without mechanical damage and lower letters compare $\mathrm{SiO}_{2}$ variations. Reducing sugars results were significant only for mechanical damage presence/absence. Other results were significant for the interaction between $\mathrm{SiO}_{2}$ variations and the presence/absence of mechanical damage.
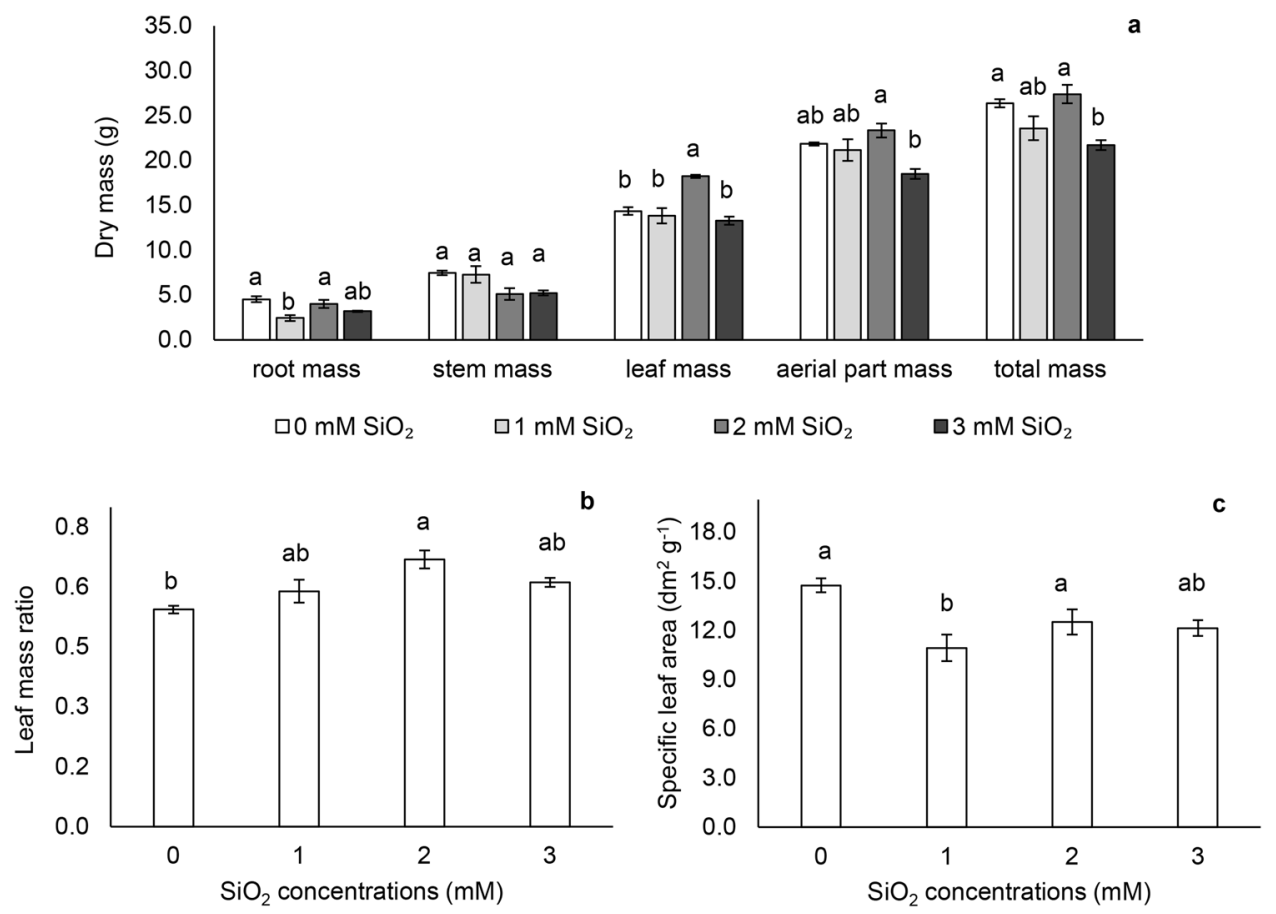

Figure 6. Biomass. (a) Dry masses of roots $(\mathrm{p}<0.01)$, stems $(\mathrm{p}<0.03)$, leaves $(\mathrm{p}<0.01)$, aerial part $(\mathrm{p}<0.01)$ and total plant $(\mathrm{p}<0.01)$; (b) leaf mass ratio $(\mathrm{p}<0.01)$; (c) specific leaf area $(\mathrm{p}<0.01)$ in Passiflora incarnata subjected to $\mathrm{SiO}_{2}$ variations. Values corresponding to the averages $\pm \mathrm{SE}$.

Leaf silicon content. The supply of $\mathrm{SiO}_{2}$ increased the $\mathrm{Si}$ content in the leaves. When $1 \mathrm{mM} \mathrm{SiO}_{2}$ was supplied, Si concentration in the leaves was intermediate and the highest content was found in plants grown with 2 and $3 \mathrm{mM} \mathrm{SiO}_{2}$ (Fig. 7). 


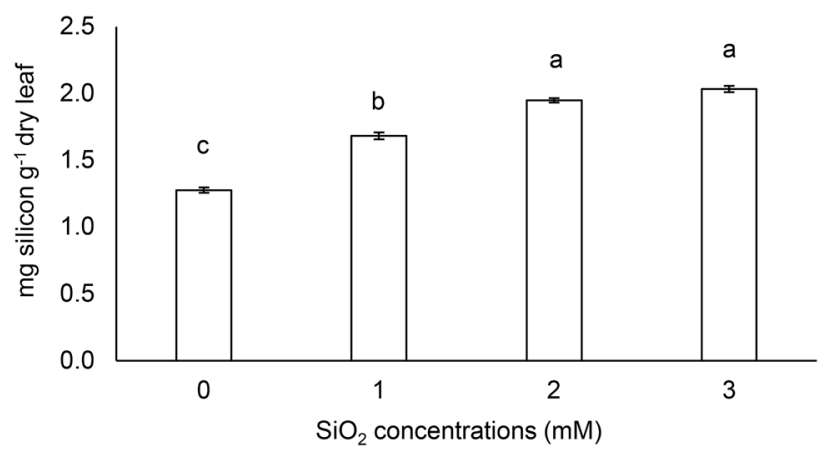

Figure 7. Silicon content in leaves from Passiflora incarnata $\mathrm{L}$. subjected to $\mathrm{SiO}_{2}$ variations. Values corresponding to the averages $\pm \mathrm{SE}$.

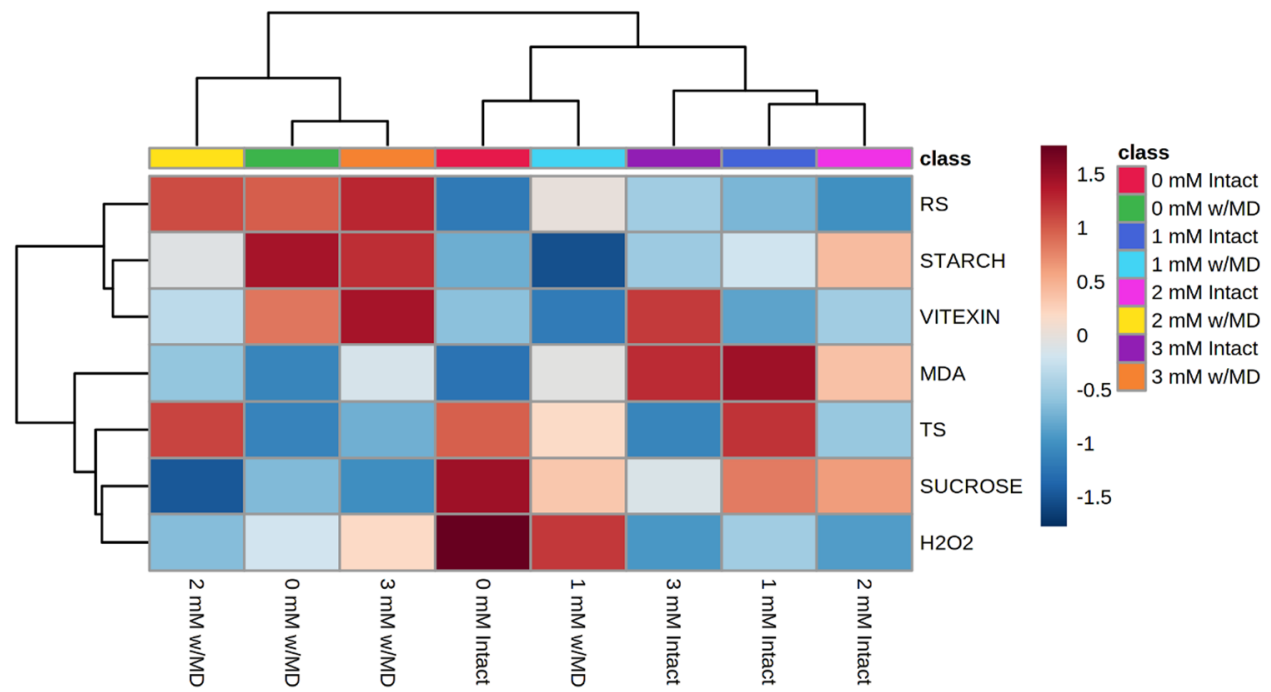

Figure 8. Heatmap. Hierarchical cluster analysis presented as a heatmap on evaluations of reducing sugars (RS), starch, vitexin, lipid peroxidation expressed by the formation of malonaldehyde (MDA), total sugars (TS), sucrose and hydrogen peroxide $\left(\mathrm{H}_{2} \mathrm{O}_{2}\right)$ in Passiflora incarnata $\mathrm{L}$. with mechanical damage (w/MD) and without mechanical damage (intact), subjected to $\mathrm{SiO}_{2}$ variations $(0,1,2$ and $3 \mathrm{mM})$. Software used to create this figure was MetaboAnalyst (v4.0, https://www.metaboanalyst.ca/).

These results indicate that the source of Si used for the conditions of this study was adequate. Si was quickly translocated to the leaves, since $\mathrm{SiO}_{2}$ supply occurred at 124 DAS and leaf collect, which resulted in biochemical evaluations, was performed at 169 DAS (Fig. 7).

Heatmap. A heatmap was drawn up to demonstrate the similarity between treatments and the correlation between biochemical variables (Fig. 8). It is possible to observe the formation of two groups in which the treatments in each group have similarity for the variables. The first group consisted of treatments with damage and 0,2 and $3 \mathrm{mM} \mathrm{SiO}_{2}$. The second group consisted of treatments with intact plants and plants with damage and $1 \mathrm{mM} \mathrm{SiO}_{2}$. The treatments in the first group showed the highest averages (red squares) for the variables reducing sugars and starch, and the lowest for sucrose and MDA. In this group, treatments 0 and $3 \mathrm{mM} \mathrm{SiO}_{2}$ with damage had the highest averages for vitexin. On the other hand, the treatments in the second group had the lowest averages for reducing sugars and high for sucrose. In this group, the intact plants treatments that received $\mathrm{Si}$ had higher MDA averages. We highlight in this group the treatment with $3 \mathrm{mM} \mathrm{SiO}_{2}$ which presented the highest vitexin average, opposite to the others, which indicates a relationship with the $\mathrm{SiO}_{2}$ level supplied. When $3 \mathrm{mM} \mathrm{SiO}_{2}$ were used in plants with or without damage, higher vitexin averages were verified. However, intact plants with $3 \mathrm{mM} \mathrm{SiO}_{2}$ revealed high MDA concentration.

\section{Discussion}

Our study results emphasize the Si action on the metabolism of plants subjected to abiotic stress, providing better performance under adverse conditions, as observed in other studies ${ }^{29}$. 
The mechanical damage in $P$. incarnata at 140 DAS stimulated remained bud's photosynthetic activity, suggesting compensatory photosynthesis ${ }^{30}$, since the removal of old branches allows interception of solar radiation better by young branches. The requirement of higher demand for photoassimilates by new tissues, can stimulate the development and photochemical activity, enabling increased electron flow ${ }^{31,32}$. It's responsible for higher production of reducing agents used in carbon assimilation, observed in the present study, respectively, by higher ETR and ФPSII.

$P$. incarnata plants with 1 and $2 \mathrm{mM} \mathrm{SiO}_{2}$ and mechanical damage were efficient in overcoming this damage and restoring themselves, which is observed in the high photochemical efficiency at $140 \mathrm{DAS}$ and high $A_{\text {net }} / \mathrm{C} i$, $A_{n e t}$ and $g_{s .}$ At $169 \mathrm{DAS}$ the supply of $2 \mathrm{mM} \mathrm{SiO}_{2}$ promoted increase of $g_{s}$ and $A_{\text {net }}$. These results are in agreement with those verified in the literature ${ }^{25,26}$, in which data of increase in $g_{s}, A_{n e t}, E$ and dry mass of leaves are verified in $P$. edulis when $\mathrm{Si}$ was supplied.

According to the study by Zhang et al. ${ }^{22}$, the supply of Si may have promoted greater expression of the genes PetE, PetF, PsbP, PsbQ, PsbW and Psb, which are important for the photochemical step of photosynthesis. Gene expression may have contributed to the production of reducing agents used in the biochemical stage of photosynthesis, as indicated in other studies ${ }^{29,33}$, and observed in the high qL at 140 DAS, presented in this study.

At 169 DAS the mechanical damage was preponderant to maintain photochemical energy's direction for the production of reducing agents, since the highest qL was observed in plants without $\mathrm{Si}$. The mechanical damage may favor photochemical activity increase, stimulated by high nitrogen demand for new tissues formation, as well as higher incident radiation stimulates nitrate absorption by the roots. Besides, the reduction of nitrate occurs mainly in leaves, as it is a strong electron drain, it can stimulate greater photochemical activity ${ }^{31}$. It is noteworthy that nitrogen source used in this work was mainly nitric.

The higher photosynthetic activity, reflected by $A_{n e t}, g_{s}$ and $A_{n e t} / C_{i}$, may have contributed to a high concentration of total and reducing sugars, directing resources for growth, biomass accumulation and lower MDA accumulation, a result that indicates low stress in plants grown with $2 \mathrm{mM} \mathrm{SiO}_{2}$ and mechanical damage. The Si supply in plants with different stress modalities promotes an increase in the activity of antioxidant enzymes, which neutralize reactive oxygen species, decreasing lipid peroxidation ${ }^{34-36}$.

Si supply was effective in signaling polyphenol synthesis, as described in the literature ${ }^{23,24}$. We highlight the increase in vitexin provided by the higher dose of Si supplied to P. incarnata. Si promotes greater activity of the PAL enzyme, which participates in the phenols and flavonoids synthesis ${ }^{23,24}$.

Potassium silicate $(5,7.5$ and $10 \mathrm{mM})$ influences apigenin ${ }^{19}$, a precursor flavone of vitexin, which may explain, in this study, the accumulation of vitexin in P. incarnata cultivated with $3 \mathrm{mM} \mathrm{SiO}_{2}$. The signaling for vitexin production is dependent on $\mathrm{Si}$ concentrations and seems not to be related to higher lipid peroxidation and activation of the enzymatic antioxidant system. Mechanical stress can also influence the activity of the PAL enzyme and other enzymes in the polyphenol pathway, as suggested by the results of Liu et al. ${ }^{28}$, and confirmed in this study in the control treatment with absence of Si and with w/MD.

In the presence of mechanical damage, plants grown with 1 and $2 \mathrm{mM} \mathrm{SiO}_{2}$ were efficient in overcoming stress and these concentrations contributed to the synthesis of polyphenols. It is suggested that these concentrations were enough to signal the PAL metabolic pathway, which promoted an increase in the polyphenol index. As observed in the evaluation of vitexin, the increased activity of the PAL enzyme is stimulated by the supply of Si, resulting in an increase in the content of other phenolic compounds, as related in other studies ${ }^{23,24}$.

Damaged plants accumulated more starch than intact ones in the absence of Si. Starch may have been the result of mechanical stress, activating the enzymatic antioxidant system that reduced free $\mathrm{H}_{2} \mathrm{O}_{2}$. Among plants that didn't receive $\mathrm{Si}$, the stress that resulted in the accumulation of starch may be related to a higher content of vitexin, since stored starch may act as source of carbohydrates for the development of new tissues, in addition to providing carbon skeletons for flavonoid synthesis. Results by Castrillón-Arbeláez et al. ${ }^{37}$ reveal that mechanical damage is related to the expression of starch synthase, demonstrating an increase in this carbohydrate. In plants with $\mathrm{Si}$, the accumulation of vitexin should not be related to starch resulting from stress, but the possible signaling triggered by the higher dose of Si supplied, acting on vitexin precursors ${ }^{19}$.

Among plants that received $3 \mathrm{mM} \mathrm{SiO}_{2}$, the absence of difference in total soluble sugars, reducing sugars and sucrose may indicate that the production of carbon skeletons was not altered. The starch concentration in plants with $3 \mathrm{mM} \mathrm{SiO}_{2}$ and mechanical damage suggests accumulation to overcome stress, similar to that observed in plants without $\mathrm{Si}$ and with mechanical damage. The supply of $1 \mathrm{mM} \mathrm{SiO}_{2}$ in plants with mechanical damage increased $\mathrm{H}_{2} \mathrm{O}_{2}$ concentration in leaves, but did not result in higher MDA. Plants with damage and Si also had lower MDA than intact plants with $\mathrm{Si}$, indicating the supply of Si under stress conditions contributes to the efficiency of the enzymatic antioxidant system ${ }^{29}$.

The $\mathrm{Si}$ supplied to intact plants resulted in an increase in lipid peroxidation, although a higher free $\mathrm{H}_{2} \mathrm{O}_{2}$ content was not detected, also pointed out by Coskun et al. ${ }^{29}$. Only the $3 \mathrm{mM} \mathrm{SiO}_{2}$ concentration was effective in increasing the vitexin content. The results observed with Si supply in intact plants indicate that the stress demonstrated by the higher MDA seems not to be related to the higher vitexin synthesis, which suggests another signaling pathway.

We discovered that $P$. incarnata showed greater photosynthetic performance when subjected to mechanical damage, which may have triggered a signaling cascade and, associated with $\mathrm{Si}$, resulted in less MDA, with damage recovery and accumulation of phenolic compounds. At a concentration equal to $3 \mathrm{mM} \mathrm{SiO}_{2}$, there was higher vitexin accumulation in the plants and a lower dry mass than other treatments. At low Si concentrations, the photosynthetic performance suggests overcoming the mechanical damage.

In P. incarnata crops, mechanical damage is performed by removing the aerial part, which can lead to an increase in vitexin production. The application of $3 \mathrm{mM} \mathrm{Si}$ is recommended to increase polyphenols and vitexin, without harming dry mass of aerial part. Supplying $3 \mathrm{mM} \mathrm{SiO}_{2}$ with increased vitexin by $150 \%$ and polyphenols by $130 \%$, suggesting the potential of $\mathrm{Si}$ in the phenolic compounds increase in plants ${ }^{23,24}$, which may be important 
in the herbal medicines development for the treatment of diseases related to the central nervous system ${ }^{9,38}$. Thus, the interaction between silicon and mechanical damage could be a tool to increase agronomic yield and commercial value of the P. incarnata crop.

\section{Methods}

Experimental conditions. The experiment was carried out at the Department of Biostatistics, Plant Biology, Parasitology and Zoology at São Paulo State University (UNESP), Botucatu (São Paulo, Brazil), geographic coordinates $22^{\circ} 53^{\prime} 09^{\prime \prime} \mathrm{W} 48^{\circ} 26^{\prime} 42^{\prime \prime} \mathrm{S}$ and $800 \mathrm{~m}$ average altitude, in a Van der Hoeven greenhouse type with pad fan and temperature about $25^{\circ} \mathrm{C} \pm 5$.

Plant material. Certified seeds of Passiflora incarnata, cultivar CF-01, were obtained through the company Centroflora Group, and registered on the platform of the Ministry of Agriculture, Livestock and Food Supply. Exsiccates were made with reproductive branches of plants obtained through $P$. incarnata seeds (CF-01) and deposited at the Herbarium Irina Delanova Gemtchujnicov (BOTU), at Institute of Biosciences, UNESP, under the code BOTU34797. The studies with plants used in this work were carried out in accordance with relevant institutional, national or international guidelines. Propagation occurred by sowing, in December 2018, in a commercial substrate composed of peat, vermiculite, carbonized rice husk and organic residue, using $40 \mathrm{~mL}$ tubes. At 81 DAS, the seedlings were transferred to hydroponics. Two plants per pot, with a $6 \mathrm{~L}$ capacity, were kept in nutrient solution number 2 by Hoagland and Arnon ${ }^{39}$, at $25 \%$ ionic strength, which was raised to $50 \%$ at 96 DAS.

Experimental design and treatments application. The experiment was installed in a randomized block design, with five replications and two plants per repetition. A $4 \times 2$ factorial design was used, with silicon dioxide $\left(\mathrm{SiO}_{2}\right)$ concentrations equal to $0,1,2$ and $3 \mathrm{mM}$ and the presence or absence of mechanical damage. At $124 \mathrm{DAS}, \mathrm{SiO}_{2}$ was added to the solution and at $136 \mathrm{DAS}$ mechanical damage was done to the main branch, by removing the aerial part of one of the plants (leaving other intact), $15 \mathrm{~cm}$ from the pot surface, maintaining a tiller. The preparation of $1 \mathrm{~L}$ of $\mathrm{SiO}_{2} 1 \mathrm{M}$ stock solution was prepared under stirring and heating at $80{ }^{\circ} \mathrm{C}$, with the addition of $0.3 \mathrm{~L}$ of $\mathrm{NaOH} 1 \mathrm{M}$ for its solubilization. When the $\mathrm{Si}$ was supplied to the nutrient solution, hydrochloric acid was used to adjust the $\mathrm{pH}$, which was kept between 5.5 and 6.5 .

Measurement of chlorophyll a fluorescence and gas exchange. Chlorophyll a fluorescence and gas exchange were evaluated at 140 and 169 DAS, using the Infra-Red Gas Analyzer, model GFS-3000 Fl-Walz, with a coupled portable modulated light fluorometer. The evaluations took place between 9 a.m. and 11 a.m. on a fully expanded leaf.

The variables evaluated were potential quantum efficiency of open PSII center $\left(\mathrm{Fv}^{\prime} / \mathrm{Fm}^{\prime}\right)$ energy fraction absorbed by PSII antenna that is dissipated as heat $(D)$, energy fraction not dissipated in the antenna that cannot be used for photochemistry stage $(E x)$, photochemical quenching (qL), electron transport rate (ETR), effective quantum efficiency of photosystem II (ФPSII), $\mathrm{CO}_{2}$ assimilation rate $\left(A_{\text {net }}, \mu \mathrm{mol} \mathrm{CO}_{2} \mathrm{~m}^{-2} \mathrm{~s}^{-1}\right)$, transpiration rate ( $E$, $\left.\mathrm{mmol} \mathrm{H}_{2} \mathrm{O} \mathrm{m}^{-2} \mathrm{~s}^{-1}\right)$, stomatal conductance $\left(g_{s}, \mathrm{mmol} \mathrm{m}^{-2} \mathrm{~s}^{-1}\right)$, and Ribulose 1,5-diphosphate carboxylase/ oxygenase (RuBisCO) carboxylation efficiency, by the $\mathrm{CO}_{2}$ assimilation rate and internal $\mathrm{CO}_{2}$ concentration in the sub-stomatal chamber $\left(A_{n e t} / C_{i} \mu \mathrm{mol} \mathrm{m}{ }^{-2} \mathrm{~s}^{-1} \mathrm{~Pa}^{-1}\right)$.

Plant material samples for biochemical analysis, vitexin and leaf silicon content. At 169 DAS leaves were collected and frozen in liquid nitrogen to determine carbohydrates, $\mathrm{H}_{2} \mathrm{O}_{2}$ and lipid peroxidation. Part of the collected leaves were dried at $38{ }^{\circ} \mathrm{C}$ in a forced ventilation oven to determine vitexin and leaf $\mathrm{Si}$ content.

Determination of total sugars, reducing sugars, sucrose and starch. The total soluble sugars were obtained by triple extraction, with $80 \%$ ethanol and supernatants were combined. The pellet from this stage was frozen for subsequent extraction of $\operatorname{starch}^{40}$. Them, starch was extracted by triple extraction with chilled $52 \%$ perchloric acid and the supernatants were pooled in falcon until reading.

The quantification of total soluble sugars was performed using the anthrone method, with a spectrophotometer reading at $620 \mathrm{~nm}$, expressed in a standard glucose curve ${ }^{41,42}$. Reducing sugars were quantified with the use of dinitrosalicylic acid (DNS), with a reading at $540 \mathrm{~nm}$ and a curve expressed in a glucose pattern ${ }^{43}$. Sucrose quantification occurred with the use of an anthrone $+30 \% \mathrm{KOH}$, with $620 \mathrm{~nm}$ reading and curve expressed in a sucrose pattern ${ }^{44}$. The starch was determined by the anthrone method, and the reading occurred at $620 \mathrm{~nm}$, with a glucose pattern curve.

Determination of hydrogen peroxide and lipid peroxidation. $\mathrm{H}_{2} \mathrm{O}_{2}$ content was determined with trichloroacetic acid (TCA) and reading on a spectrophotometer at $390 \mathrm{~nm}^{45}$. Lipid peroxidation was determined with thiobarbituric acid (TBA) and trichloroacetic acid (TCA) and expressed by the formation of malonaldehyde $(\mathrm{MDA})^{46}$.

Determination of vitexin and polyphenols. Determination of vitexin according to Wosch et al. ${ }^{47}$, used $200 \mathrm{mg}$ of crushed dry leaves $\left(38^{\circ} \mathrm{C}\right)$, with the addition of $8 \mathrm{~mL}$ of $60 \%$ ethanol in $15 \mathrm{~mL}$ test tubes. Then, the tubes were vortexed $(15 \mathrm{~s})$ and submitted to an ultrasound bath $(30 \mathrm{~min})$. Each extract was filtered with cotton and the volume was made up with solvent extractor (ethanol). Samples were filtered with a Millex LCR filter (non-sterile $0.45 \mu \mathrm{m} 13 \mathrm{~mm}$ PTFE membrane) and placed in amber glass bottles at $4{ }^{\circ} \mathrm{C}$. The quantification of vitexin in the 
samples was performed in a High-Performance Liquid Chromatography (uv HPLC focused Thermo FisherScientific) with gradient pump and UVVIS detector and a C18 reverse phase column $(150 \times 4.6 \mathrm{~mm}$ and $5 \mu \mathrm{m}$ particle diameter). The mobile phase consisted of a $0.5 \%$ gradient acetic acid in ultrapure water (A), methanol (B) and acetonitrile (C), HPLC grade, with a flow rate of $1 \mathrm{~mL} / \mathrm{min}$ for $30 \mathrm{~min}$ and detection wavelength $340 \mathrm{~nm}$. The standard used was Sulpleco, degree of purity $\geq 95 \%$ and the linearity curve of vitexin showed a correlation coefficient, $\mathrm{y}=0.8233 \mathrm{x}-3.9105, \mathrm{R}^{2}=0.9959$. Polyphenols were evaluated by Dualex Scientific optical sensor at $375 \mathrm{~nm}^{48}$, at $165 \mathrm{DAS}$, on both sides of the second and third leaves of each plant fully expanded, avoiding the central rib.

Leaf silicon content. Leaf Si content was determined using hydrochloric acid and ammonium molybdate, with a reading at $410 \mathrm{~nm}^{49}$.

Growth parameters measurement. Root, stem and leaves of the intact plant were collected at 169 DAS and after determining the leaf area, by leaf area integrator LI-3100C area meter LI-COR, they were subjected to drying at $38{ }^{\circ} \mathrm{C}$ until constant dry mass.Growth rates were evaluated by masses averages of dry roots (RDM), stems (SDM), leaves (LDM), aerial part (APDM) and total (TDM). The leaf area (LA) was also evaluated. From these data, leaf mass ratio (LMR) was calculated using the LDM/TDM ratio, and specific leaf area (SLA), LA/ $\mathrm{LDM}^{50}$.

Statistical analysis. The results were subjected to variance analysis at $5 \%$ significance. The averages were compared by the Tukey test ( $5 \%$ significance).

A heatmap was prepared from the hierarchical cluster analysis, performed using the online version of MetaboAnalyst $4.0^{51}$, to assess the relationship between treatments and biochemical variables. Variables were standardized and the Euclidean distance between treatments was considered.

Received: 6 February 2021; Accepted: 1 November 2021

Published online: 11 November 2021

\section{References}

1. Killip, E. P., Cuatrecasa, J., Smith, L. B. \& Ewan, J. Supplemental notes on the American species of Passifloraceae, with descriptions of new species. Contrib. United States Natl. Herb. 35, 1-23 (1968).

2. Gremilion, K. J. The development of a mutualistic relationship between humans and maypops (Passiflora incarnata L.) in the southeastern United States. J. Ethnobiol. 2, 135-155 (1989).

3. Dhawan, K., Dhawan, S. \& Sharma, A. Passiflora: A review update. J. Ethnopharmacol. 94, 1-23 (2004).

4. Elghobashy, K. A., Eldanasoury, M. M., Elhadary, A. A. \& Farid, M. Phytochemical constituent, HPLC profiling and antioxidant activity of Passiflora incarnata and Arctium lappa leaves extracts. Int. J. Vet. Sci. 1, 42-49 (2019).

5. Dhawan, K., Kumar, S. \& Sharma, A. Aphrodisiac activity of methanol extract of leaves of Passiflora incarnata Linn. in mice. Phyther. Res. 17, 401-403 (2003).

6. Kim, G. H. et al. Improvement in neurogenesis and memory function by administration of Passiflora incarnata L. extract applied to sleep disorder in rodent models. J. Chem. Neuroanat. 98, 27-40 (2019).

7. Guerrero, F. A. \& Medina, G. M. Effect of a medicinal plant (Passiflora incarnata L.) on sleep. Sleep Sci. 10, 96-100 (2017).

8. RENISUS - Relação Nacional de Plantas Medicinais de Interesse ao SUS. Departamento de Assistência Farmacêutica e Insumos Estratégicos Coordenação Geral de Assistência Farmacêutica Básica 24-25 (2009).

9. Aslam, M. S. Pharmacological potential of vitexin. Indian Res. J. Pharm. Sci. 2, 114-122 (2015).

10. Chen, Y. et al. Vitexin prevents colitis-associated carcinogenesis in mice through regulating macrophage polarization. Phytomedicine 83, 153489 (2021).

11. Abubakar, S., Al-Mansoub, M. A., Murugaiyah, V. \& Chan, K. L. The phytochemical and anti-inflammatory studies of Dillenia suffruticosa leaves. Phyther. Res. 33, 660-675 (2019).

12. Abdulai, I. L. et al. Multitargeted effects of vitexin and isovitexin on diabetes mellitus and its complications. Sci. World J. https:// doi.org/10.1155/2021/6641128 (2021).

13. de Oliveira, D. D., da Silva, C. P., Iglesias, B. B. \& Beleboni, R. O. Vitexin possesses anticonvulsant and anxiolytic-like effects in murine animal models. Front. Pharmacol. 11, 1-9 (2020).

14. World Health Organization. Depression and Other Common Mental Disorders: Global Health Estimates (World Health Organization, 2017).

15. Pacheco, A. C. et al. The use of animal manure in the organic cultivation of Passiflora incarnata L. increases the content of phenolic compounds in the leaf and the antioxidant activity of the plant. Org. Agric. https://doi.org/10.1007/s13165-021-00361-3 (2021).

16. Reimberg, M. C. H., Colombo, R. \& Yariwake, J. H. Multivariate analysis of the effects of soil parameters and environmental factors on the flavonoid content of leaves of Passiflora incarnata L. Passifloraceae. Rev. Bras. Farmacogn. 19, 853-859 (2009).

17. Zucareli, V., Henrique, L. A. V. \& Ono, E. O. Influência da luz e da temperatura na germinação de sementes de Passiflora incarnata L. J. Seed Sci. 37, 162-167 (2015).

18. Campos, M., Uliana, M., Montero, D. V., Lima, G. \& Ming, L. C. Effect of organic fertilization on biomass production and bioactive compounds in Passiflora incarnata L. Int. J. Phytocosmetics Nat. Ingredients 2, 11 (2015).

19. Carneiro-Carvalho, A. et al. The role of silicon fertilization in the synthesis of phenolic compounds on chestnut plants infected with P. cinnamomi and C. parasitica. J. Plant Dis. Prot. 127, 211-227 (2020).

20. Wu, Z. et al. Comparative responses to silicon and selenium in relation to antioxidant enzyme system and the glutathione-ascorbate cycle in flowering Chinese cabbage (Brassica campestris L. ssp chinensis var utilis) under cadmium stress. Environ. Exp. Bot. 133, $1-11(2017)$.

21. Yao, X. et al. Silicon improves the tolerance of wheat seedlings to ultraviolet-B stress. Biol. Trace Elem. Res. 143, 507-517 (2011).

22. Zhang, Y. et al. Beneficial effects of silicon on photosynthesis of tomato seedlings under water stress. J. Integr. Agric. 17, 2151-2159 (2018).

23. Shetty, R. et al. Silicon-induced changes in antifungal phenolic acids, flavonoids, and key phenylpropanoid pathway genes during the interaction between miniature roses and the biotrophic pathogen Podosphaera pannosa. Plant Physiol. 157, 2194-2205 (2011).

24. Rahman, A., Wallis, C. M. \& Uddin, W. Silicon-induced systemic defense responses in perennial ryegrass against infection by Magnaporthe oryzae. Phytopathology 105, 748-757 (2015).

25. Costa, B. N. S. et al. Silício no crescimento e estabilidade genética de plantas de maracujazeiro. Acta Sci. Agron. 38, 503-511 (2016). 
26. Costa, B. N. S. et al. Morpho-anatomical and physiological alterations of passion fruit fertilized with silicon. Pesqui. Agropecu. Bras. 53, 163-171 (2018).

27. Técnico, I. et al. Instituto de Investigaciones Fundamentales en Agricultura Tropical “Alejandro de Humboldt". Doctor 5, 1-5 (2000).

28. Liu, M. M. et al. Responses of phenolic acid and defensive enzyme activities to mechanical damage in Artemisia frigid. Chin. J. Plant Ecol. 41, 219-230 (2017).

29. Coskun, D. et al. The controversies of silicon's role in plant biology. New Phytol. 221, 67-85 (2019).

30. Fini, A. et al. Effects of different pruning methods on an urban tree species: A four-year-experiment scaling down from the whole tree to the chloroplasts. Urban For. Urban Green. 14, 664-674 (2015).

31. Calatayud, Á., Roca, D., Gorbe, E. \& Martínez, P. F. Physiological effects of pruning in rose plants cv. Grand Gala. Sci. Hortic. 116, 73-79 (2008).

32. Suchocka, M., Swoczyna, T., Kosno-Jończy, J. \& Kalaji, H. M. Impact of heavy pruning on development and photosynthesis of Tilia cordata Mill. trees. PLoS ONE 16, e0256465 (2021).

33. Sales, A. C. et al. Silicon mitigates nutritional stress in quinoa (Chenopodium quinoa Willd.). Sci. Rep. 11, 14665 (2021).

34. Resende, R. S. et al. Leaf gas exchange and oxidative stress in sorghum plants supplied with silicon and infected by Colletotrichum sublineolum. Phytopathology 102, 892-898 (2012).

35. Shi, Y. et al. Silicon enhances water stress tolerance by improving root hydraulic conductance in Solanum lycopersicum L. Front. Plant Sci. 7, 1-15 (2016).

36. Zhu, Z., Wei, G., Li, J., Qian, Q. \& Yu, J. Silicon alleviates salt stress and increases antioxidant enzymes activity in leaves of saltstressed cucumber (Cucumis sativus L.). Plant Sci. 167, 527-533 (2004).

37. Castrillón-Arbeláez, P. A., Martínez-Gallardo, N., Arnaut, H. A., Tiessen, A. \& Délano-Frier, J. P. Metabolic and enzymatic changes associated with carbon mobilization, utilization and replenishment triggered in grain amaranth (Amaranthus cruentus) in response to partial defoliation by mechanical injury or insect herbivory. BMC Plant Biol. 12, 1-22 (2012).

38. de Oliveira, D. R. et al. Flavones-bound in benzodiazepine site on GABA A receptor: Concomitant anxiolytic-like and cognitiveenhancing effects produced by Isovitexin and 6-C-glycoside-Diosmetin. Eur. J. Pharmacol. 831, 77-86 (2018).

39. Hoagland, D. R. \& Arnon, D. I. The water-culture method for growing plants without soil. Calif. Agric. Exp. Stn. 397, 32 (1950).

40. Garcia, I. S., Souza, A., Barbedo, C. J., Dietrich, S. M. C. \& Figueiredo-Ribeiro, R. C. L. Changes in soluble carbohydrates during storage of Caesalpinia echinata LAM. (Brazilwood) seeds, an endangered leguminous tree from the Brazilian Atlantic Forest. Braz. J. Biol. 66, 739-745 (2006).

41. Morris, D. L. Quantitative determination of carbohydrates with Dreywood's anthrone reagent. Science 107, 254-255 (1948).

42. Yemm, E. W. \& Willis, A. J. The estimation of carboydrates in plant extracts by anthrone. Biochem. J. 57, 508-514 (1954).

43. Miller, G. L. Use of dinitrosaiicyiic acid reagent for determination of reducing sugar. Anal. Chem. 31, 426-428 (1959).

44. Passos, L. P. Métodos Analíticos e Laboratoriais em Fisiologia Vegetal 223 (1996).

45. Alexieva, V., Sergiev, I., Mapelli, S. \& Karanov, E. The effect of drought and ultraviolet radiation on growth and stress markers in pea and wheat. Plant Cell Environ. 24, 1337-1344 (2001).

46. Teisseire, H. \& Guy, V. Copper-induced changes in antioxidant enzymes activities in fronds of duckweed (Lemna minor). Plant Sci. 153, 65-72 (2000).

47. Wosch, L., dos Santos, K. C., Imig, D. C. \& Santos, C. A. M. Comparative study of Passiflora taxa leaves: II. A chromatographic profile. Rev. Bras. Farmacogn. 27, 40-49 (2017).

48. Goulas, Y., Cerovic, Z. G., Cartelat, A. \& Moya, I. Dualex: A new instrument for field measurements of epidermal ultraviolet absorbance by chlorophyll fluorescence. Appl. Opt. 43, 4488-4496 (2004).

49. Korndörfer, G. H., Pereira, H. S. \& Nolla, A. Análise de silício: Solo, Planta e Fertilizante (2004).

50. Benincasa, M. M. P. Análise de Crescimento de plantas: Noções Básicas (Funep, 2003).

51. Chong, J., Wishart, D. S. \& Xia, J. Using MetaboAnalyst 4.0 for comprehensive and integrative metabolomics data analysis. Curr. Protoc. Bioinforma. 68, e86 (2019).

\title{
Acknowledgements
}

We thank the Coordination for the Improvement of Higher Education Personnel (CAPES, Brazil), for the financial support through a master's scholarship and the company Centroflora Group, for the supply of Passiflora incarnata L. seeds.

\section{Author contributions}

J.A.V.P.; L.G.G.; F.G.C. and C.S.F.B. designed the study; J.A.V.P.; F.G.C.; G.R.B. and M.A.R.V. conducted the study; J.A.V.P.; G.R.B.; F.G.C.; L.J.G.G. and C.S.F.B. wrote the main manuscript text; J.A.V.P.; G.R.B.; F.G.C. and M.A.R.V. prepared figures; All authors reviewed the manuscript.

\section{Competing interests}

The authors declare no competing interests.

\section{Additional information}

Correspondence and requests for materials should be addressed to F.G.C.

Reprints and permissions information is available at www.nature.com/reprints.

Publisher's note Springer Nature remains neutral with regard to jurisdictional claims in published maps and institutional affiliations.

\begin{abstract}
(c) (i) Open Access This article is licensed under a Creative Commons Attribution 4.0 International cc. License, which permits use, sharing, adaptation, distribution and reproduction in any medium or format, as long as you give appropriate credit to the original author(s) and the source, provide a link to the Creative Commons licence, and indicate if changes were made. The images or other third party material in this article are included in the article's Creative Commons licence, unless indicated otherwise in a credit line to the material. If material is not included in the article's Creative Commons licence and your intended use is not permitted by statutory regulation or exceeds the permitted use, you will need to obtain permission directly from the copyright holder. To view a copy of this licence, visit http://creativecommons.org/licenses/by/4.0/.
\end{abstract}

(c) The Author(s) 2021 